Doctor of Pedagogical Sciences, Full Professor, OLENA SEMENOG Institute of Pedagogical Education and Adult Education, Ukraine Address: 9 Berlynskoho St., Kyiv, 04060, Ukraine E-mail: olenasemenog@gmail.com

\title{
TRAINING OF MASTERS IN PHILOLOGY IN UKRAINE AND ABROAD: SEARCH FOR EDUCATIONAL STRATEGIES
}

\begin{abstract}
The paper outlines the modernization experience of philology Master programs in Ukraine, the USA, Poland and Russia. It has been proved that the Masters' training is on the search educational strategies phase, which allows to form a single educational space on the principles of internationalization, institutionalization, integration, cultural convergence, common goals and values. An important field of Masters' training is a competency-based approach. It is based on the idea of flexibility, variability of programs, and profiling, philological integration with other humanities, criteria, standards and principles of improving the quality of education. Attention is focused on the formation of constructive-technological, operational, educational, reflective, educational, qualimetric and creative skills of future teachers. Among the perspective forms of education lecture is distinguished as it is focused on the co-creation and co-thinking of lecturer and students, monographic lectures. Among innovative teaching methods and assessment of Master training are selected case-method, cluster, reference compendium, portfolio, performance tests. The variability of final work is defined as an effective way of learning individualization. It has been proved that the result of Master's training should be the specialist with a high level of social maturity, active citizenship, education, culture and responsibility for his professional and scientific activity.
\end{abstract}

Key words: university, Master philological training, competence approach, professional competence, educational technologies.

\section{INTRODUCTION}

The main criterion of assessing the Master's educational system is primarily the demand for graduates in the labour market and wide opportunities for self-realization in the most significant areas of professional and public life. To ensure the quality of higher education and its integration into European and world educational community the Ministry of Education approved the "Concept of training Masters in Ukraine" (decree of 10.02.2010 № 99), which includes the division of Master’s programs in research, professional and career components; extension of normative Masters' term study of all directions to 1,5-2 years; the possibility of joint inter-university and international Master's programs and others. However, for various reasons, appropriate measures were inhibited.

The Law of Ukraine "About Higher Education" (2014), Art. 5 (Part II. "Levels, degrees and higher education qualifications") determines that the Master's degree is acquired on the basis of previously acquired a Bachelor's degree; volumes of educational and vocational training programs constitute 90-120 credits ECTS, and education and research -120 . Master's level of higher education involves gaining in-depth theoretical and practical knowledge and skills in the chosen specialty, the general principles of the 
methodology of scientific and professional activity (Про вищу освіту : Закон України, 2014). There is a need to prioritize Master training.

Websites analysis of the universities and statistical reports of Ministries of Education and Science of different countries (Офіційний сайт Міністерства освіти і науки Украӥни; Офіиійний сайт Міністерства освіти і науки Російської Федераиії; Glazer-Raymo, 2005) certifies the request for profession translator, journalist, editor, publisher, whose specific professional activity is the ownership of word and style, understanding of building, reading, commenting, analyzing, modeling text, and ability to argument. Demandable is a teacher of language and literature profession, his possession of practical skills of designing, constructing, modeling the structure and content of the educational process in the humanities.

The specificity of Masters in Philology professional activity is mastering the practically oriented specialized competences. This refers to the mastering of the word and comprehension style, understanding reading constructions, commenting, analyzing, modeling text on understanding the mechanisms and laws of communication, reasoning ability. Employers' requirements are stressed on such professional important features as creativity, sociability, communication skills, verbal impact on the interlocutor's effectiveness, the desire to establish and maintain verbal contact, control and correction of communicative behaviour (their own and interlocutor), a high degree of communication debatable relevance and use of stylistically colored linguistic resources, focus on selfexpression and self-development. In this context, it is important to emphasize Masters' training according to the Bologna strategies and the Law of Ukraine "About Higher Education" (2014).

Scientific studies are valuable if include the international experience of Master's training, including gains of higher education in Germany, the UK, the USA, Russia, where attention is focused on the development of the student's creative personality.

THE AIM OF THE STUDY

Within the article we summarize some aspects of the modernization experience of Master in Philology in the USA, the UK, Poland and Russia.

\section{THEORETICAL FRAMEWORK AND RESEARCH METHODS}

In the theoretical analysis of Master's training the researches of innovative development in higher education are of the scientific value (B. Andruschenko, W. Flint, L. Hrynevych, W. Meadow, N. Nychkalo M. Zgurovsky, I. Zyazyun, and others). The scientific researches of Master's problems and, in particular, philological education in Ukraine, the USA, Poland, Russia are the source base (N. Avshenuk, N. Bidyuk, O. Goroshkina, G. Klochek, E. Kovtun, M. Maevskii, O. Matvienko, O. Ogienko, L. Puhovska, S. Rodionova, N. Sergieva, I. Sokolova, O. Zinovatna).

The methodological bases of the research system served ideas, synergistic, competence, approaches to business oriented training.

Among the methods used in the study, we define, in particular, such as analysis, synthesis, comparison, generalization - for study of official and legal documents, scientific works of native and foreign scientists, scientific and methodological information given on the websites of universities.

\section{RESULTS}

Study of scientific and critical literature supports the conclusion that nowadays Master's in Philology education in the above mentioned countries is characterized by the search for educational strategies, which allows only educational community on the principles of internationalization, institutionalization, integration, cultural convergence, 
common goals and values. In teaching science and practice the attention is focused on systematic, synergetic, competence, cultural, axiological, contextual approaches to Master's in Philology training. The system approach allows us to consider training as integral unit with the structural, functional and genetic relationships; personality and activity. It increases attention to the personality and professional skills, abilities, and subjective experience. Synergistic approach contributes to the understanding of the training process as self-development education system that encourages self-education of personality. Contextual approach means that the forms, methods and means of action in higher education in line with future professional activities and are focused on the professional development. According to the cultural approach cultural assimilation in the educational space requires professional production of ideological position, tolerance and awareness of the word value. Implementation of axiological and textual approach provides professional text orientation, values formation and development of the individual's linguistic, literary, aesthetic abilities.

Nowadays, the leading position in the educational strategy is paid to a competency approach. It is based on the ideas of flexibility and variability of educational programs, profiling, and pragmatic orientation, philology integration with other humanities, criteria, standards and principles of improving the education quality. However, the characteristics of competences proposed by native and foreign researchers do not always reflect the common ideas and goals on education and spiritual and moral foundations of life.

The US experience, Polish achievements as well as Russian focus on the development of the student's creative personality show that Master's training conceptual foundations should take into account a number of social, human, intellectual and cultural capital theories, career guidance, constructive and cognitive, continuous education, learneroriented, competence education and fundamental provisions should be scientific and methodological, theoretical and professional preparation, focused on the person who "is able to social mobility, strategic design vector of his career and moral self-regulation" (Старикова, 2010). To ensure the Master's training system in accordance with European educational standards it is important to keep national educational traditions and consider the best achievements of foreign countries.

The Master's programs task, particularly in the analyzed countries is to train young researchers towards success in career, in various scientific fields or disciplines. In the USA Masters' educational programs in higher education are of different orientation and profiles in scientific (research) specialization and of applied (professional) character. The University Bemidji (MN) Master Program in English involves the study of British and American literature, cinema and folk traditions and aims at developing critical writing skills (Bemidji State University: Department of English). After the program's completing graduate have the possibility of employment as film or literary critic, folklore specialist or lecturer. Функціонують і програми 3 підготовки фахівців 3 видавничого бізнесу, менеджерів, магістрів мистецтв у галузі навчання англійської мови, магістрів мистецтв у галузі навчання викладанню англійської мови, магістрів наук з освіти 3 викладання англійської мови. There also programs of training in publishing, management, Master of Arts in Teaching English, Master of Education in Teaching English.

The means of increasing the popularity of philology direction is interdisciplinary specialties, based on scientific schools with professor teaching staff in educational institutions (Georgia State University: English Education (MAT)). Some aspects of creating multiple Master's training in the USA are suitable for use in Ukraine. O. Zinovatna conducting comparative research concludes that our universities within the philological 
Master specialty "Language and Literature (English)" may exist at least at three graduate programs with different orientations, linguistic or literary (scholar-teacher), psychological and pedagogical (teacher-methodologist for schools or high schools), linguistic in professional direction (the use of language in various fields) etc. (Зіноватна, 2011). However, interdisciplinary courses in Ukraine are not yet widespread.

Among these three types of Master's degree are research courses, specialized / advanced courses, professional / practical courses. In higher educational institutions of Russia and Ukraine dominated Scientific Research programs are: "Russian Literature" "Russian", "Theory of Language", "Comparative Studies", "Mythology and folkloristic" and others. However, gradually increasing in Russian high school are the number of applications (practice-oriented) Master's programs ("Russian as a foreign language", "Information technology in the humanities in general", "Theory and practice of speech communication", "Language and media advertising", "Business communication and advertising" etc.). Creating Master's of Science programs, as experts note, is perspective in the development among Master in Philology in Ukrainian universities.

The content of teaching professional training in Russia and Ukraine are governed by public legal documents. In the USA, instead it is solved by each state. To receive a license to teach is possible only if you complete a full cycle of Master training and pass the professional examination in a special Commission staff with professional standards. The specific feature of learning content of Master's in Philology programs in Poland is focused on the formation of linguistic, literary, cultural, communicative competences, and it is possible for a teacher to receive a diploma only after graduating two-year Master's degree, for example, the Institute of Education in Wroclaw University or through the system of distance learning (П'ятакова, 2001).

Educational and professional Master's programs in each country involve the formation in future teachers' constructive and technological (knowledge of modern educational technologies, skills and ability to plan, design and implement various educational activities), operational and pedagogical (possession of specific technologies, methods and techniques of training, providing an educational process in a professional and pedagogical level), reflexive and pedagogical (related to the skills of critical evaluation of their academic work results, which make it necessary to do corrections) qualimetric (ability to develop and apply the most optimal objective measurement tools of student achievements), creative (ability to design innovative forms of creative educational activities) skills (Старикова, 2010; Bemidji State University: Department of English, 2014). To maintain the knowledge of the personality's professional development, methods and technologies of self-education and self-regulation, the ability to organize the activities of professional level, mastering the necessary culture of thinking, the ability to creativity is rapidly growing are applied.

For this purpose the US high school lecture is aimed at changin the strategy of teaching, so the lectures are oriented at cooperation and argumentative dialogue between the lecturer and the students. In addition, lectures-dialogues, lecture-conversations, lecturevisualization, lecture-discussion have been introduced. Lectures in Russian universities (methodological lecture, lecture-integration, overview and repetitive, problem, an interactive lecture, lecture-conference) are created on the scientific and theoretical basis of mastering university linguistic methods application.

Ukrainian specialists pay special attention to the specifics of lectures on various linguistic disciplines. Analytical lectures in grammar of the modern Ukrainian language and historical grammar of the Ukrainian language differ because there are different methods of 
modern language analysis, historical and linguistic analysis techniques, problems, language material. Methods of interpretation also differ as they affect the specific training lecture (Сергиева, 2012). This observation is significant in the view of the fact that students must pass the magistracy assistant practice, develop and conduct the lectures, workshops, seminars with different linguistic disciplines of chosen specialization.

Value for use in Ukrainian higher education for graduate department is such form of education as lecture-monograph (Wykład monograficzny), which is offered in Polish higher education at Masters' department (Szerlag, 2008). The teacher, building his course according to requirements for this training form, carefully selects didactic material, refers to his own research and scientific refinement, and he also has his own vision of the studied problems in the linguistics and literary studies.

Educational and professional Master's programs in the analyzed countries provide us to conduct the lectures filled with heuristic, research methods (hypothesis testing, modeling). In this context, scientific and practical interest is the model (strategy) research of Master's raining created by a British scientist Griffiths, based on the relationship of research-based learning (RBL), a research-based teaching (research-based teaching, RBT) (Griffiths, 2004), according to which in an auditorium classes and during independent work a research component is introduced to perform individual research projects within research universities.

As an example, we note that in 2014 undergraduates participated in Polish pilot international competition "Sustainable Development - Science debut" held under the patronage of the European Parliament President (2009-2012), Professor Jerzy Buzek, President of NAPS of Ukraine Vasyl Kremen and Academician-Secretary of the Professional Education and Adult Education Department of NAPS of Ukraine, member of NAPS of Ukraine N. Nychkalo. The participants with great interest studied the methodological implementation of social and economic ideas of sustainable development in Ukraine, transformation of purport orientations of youth under globalization and European integration processes; Ukrainian communicative context factors in the European space (Ничкало, 2014).

In Masters' preparation in American higher education, partly in Russian education, among innovative teaching methods case-method (case-study) is used, the essence of which is that students should understand the real professional situation and make a decision; cluster. It is an image organization called educational material that shows the semantic field of a certain concept, performance tests or performance tests that are used and skills, as well as monitoring and evaluation form (for example, to develop and show a fragment of lectures / practical classes of philological sciences on a topic, make a report, prepare a plan interviews with cultural worker), and such forms and methods of learning as to conduct training diary (learning journal), analytical writing (autobiographical) and concise essays "minute" composition (one minute papers), the organization of group discussions (brainstorming, buss groups), presenting projects, simulation teaching situations, creating a portfolio etc.

Innovative classes require systematic training of their members, stimulate the intellectual development of creative activity, develop the capacity for deep analysis of the facts, and create critical judgments. For this purpose in the US a significant role is paid to independent work, which is led by the teacher as an individual consultant tutor, is provided methodically and is subjected to individual student's educational program, and uses methods of self-reflection, individual educational trajectory as a means of creative 
realization of personal potential. In Russia and Ukraine tutor's activities, his roles, functions, competency of tutor teacher is at a developmental stage.

An effective way to individualize learning process is the variability of final work. Usually in the USA, educational program provides from two to seven options of final work, the most common of which are Master's thesis, research project (usually applied nature) and the portfolio management. Scientific research is a kind of "problem-search training" (enquiry-based learning, EBL) work for Masters which brings the formation of selfmotivation and scientific discussion to the learning process; development of analytical and critical thinking. Students can choose between the Master's thesis and research project, which is closely linked with the needs of school facilities, writing essays, teacher portfolios, test and so on.

In Russia it is proposed to create Master's thesis as an independent logical studies associated with the solution of scientific or practical tasks in a form of project portfolio (student's individual academic achievements folder, essay containing the text of the outstanding scientist with comments from an article or conference report, a note in the newspaper, a presentation on the topic during the exam. In Ukraine, this innovation needs understanding due to lack of the evaluating methods and conservatism.

In the analyzed countries teachers are interested in cooperation and interaction within humanities, philology and IT. The main subject of linguistics, literature, history is texts with all the verbal and nonverbal components and the understanding of the text is the understanding of life era. Attracting new information technologies enables storing cultural and historical information contained in texts of different ages into electronic literature funds; activates the development of corpus lexicography, philological information science, etc.; provides integration of literature, art, language, information science etc. Future teachers' mastering foundations of information technologies and methodology of their use allows pedagogical work to be more productive, creative, contributes to the expressed motivation to design new class models. It is essential, though, to prioritise necessary information, to develop abilities by means of dialogue, to meet professional and personal needs and conduct analytical studies.

Theoretical analysis of practical experience and research results from Master in philological education in the United States, Poland, Russia, and Ukraine makes it possible to identify a number of problems. Master in Philology training should be marked by proactive nature, but experience of higher educational establishments shows that the process of education is still closed and conservative according to the curriculum. Experts criticize local names of some courses and lack of integrity and correlation with future practically oriented profession. Masters' programs are often quite poorly oriented on integrated modular approach that includes theoretical studies, independent work, practical training (research and teaching) practice.

Due to the increased need of employment interactive forms in Ukrainian universities it is important to review the system of assessment tools, starting with the current and ending with final state certification. Scientists' debate as for the proposal to pass the exam in the form of business games, solving situational problems that will test together acquired general and professional competences.

It should more clarify the specific of applied philological programs, practically oriented range of competencies that are important to form in Masters during interactive classes and teaching practices.

Among the tasks of Master training we distinguish formation of future teachers' assessment competence, which involves the acquisition of targeting, analytical, 
methodological, prognostic activity, evaluation, effective knowledge and skills of teaching experience. In the USA actively implemented are standards and principles of assessment. There exists international and national associations' assessment; in Russian and Ukrainian Master courses show the lack of knowledge assessment and skills in Masters' programs.

\section{CONCLUSIONS}

Thus, the introduction of multi-level training required reviewing final requirements for the training of Master in Philology. In the United States the attention is focused primarily on the development of competencies as professional and managerial nature. In Russian universities generally developed and "work" state standards of competency training are oriented on innovative professional activities. To promising ideas worth to use Ukrainian higher education and further study of scientific studies we refer strengthening pragmatic spirit of Master training, interactive forms and methods of learning, variability of final work and final testing. At result the master teacher training should be done by professional teacher with a high level of social maturity, education, culture, understanding the nature of person and society and their relationship in the development.

\section{REFERENCES}

1. Bemidji State University: Department of English. (2014). Retrieved 01.10.2014 from : http://bemidjistate.edu/academics/departments/english/ate.

2. Georgia State University: English Education (MAT). (2014). Retrieved 01.10.2014 from : http://msit.gsu.edu/1452.html.

3. Glazer-Raymo, J. (2005). Professionalizing Graduate Education: The Master's Degree in the Marketplace. ASHE Higher Education Report, Vol. 31, No 4, p. 137.

4. Griffiths, R. (2004). Knowledge production and the research-teaching nexus: the case of the built environment disciplines. Studies in Higher Education, Vol. 29(6), p. 709-726 (in English).

5. Szerlag, A. (2008). Funkcje szkoły wyższej w kontekście procesu Bolońskiego [The functions of higher education in the context of the Bologna process]. Problemy edukacji w szkole wyższej, p. 16-29 (in Polish).

6. Зіноватна, О. М. (2011). Професійна підготовка філологів магістерського рівня в університетах США [Professional Training of Master's level philologists in the United States] PhD. thesis. Черкаси, p. 300 (in Ukrainian).

7. Ничкало, Н. (2014.) «Сталий розвиток - Науковий дебют 2013»: нові результати [“Sustainable Development - Science debut 2013": new results]. Порівняльна професійна педагогіка [Comparative Professional Pedagogy], No 2, p. 229-236 (in Ukrainian).

8. Офіиійний сайт Міністерства освіти і науки Украйни [The official site of the Ministry of Education and Science of Ukraine]. (2014). Retrieved 01.10.2014 from: http://www.education.gov.ua (in Ukrainian).

9. Офіиійний сайт Міністерства освіти і науки Російської Федерації [The official website of the Ministry of Education and Science of the Russian Federation]. (2014). Retrieved 01.10.2014 from : http://www.ed.gov.ru/koi8/. (in Russian).

10. Про вищу освіту : Закон України. (2014) [About Higher Education: Law of Ukraine] // Урядовий кур'єр. Орієнтир, No 21, p. 7-18 (in Ukrainian).

11. Про Концепцію організації підготовки магістрів в Україні [About the Concept of training masters in Ukraine]. (2014). Retrieved 01.10.2014 from : http://osvita.ua/legislation/Vishya_osvita/6670 (in Ukrainian). 
12. П’ятакова, Г. (2011). Особливості підготовки магістрів за спеціальністю «українська філологія» у львівському та вроцлавському університетах [Preparation features of masters" degree in "Ukrainian philology" in Lviv and Wroclaw University]. Вісник Львівського університету [Lviv University Journal], No 27, p. 155-162 (in Ukrainian).

13. Сергиева, Н. С. (2012). Магистратура как качественно новый уровень высшего профессионального филологического образования: проблемы становления [Master as a new level of higher professional education Philology: problems of formation]. Информачионный бюллетень Совета по филологии Учебно-методического объединения по классическому университетскому образованию []Information Bulletin of Philology Board of Learning Methodical Community on classical university education], No 14, p. 71-92 (in Russian).

14. Старикова, О. Г. (2010). Современные образовательные стратегии высшей школь: теоретико-методологические основы [Modern educational strategies of high school: theoretical and methodological foundations], Ростов н/Д, p. 434 (in Russian). 